\title{
Albatross response to survey vessels: implications for studies of the distribution, abundance, and prey consumption of seabird populations
}

\author{
K. D. Hyrenbach* \\ Graduate Department (Q-0208), Scripps Institution of Oceanography, University of California, San Diego, \\ 9500 Gilman Dr., La Jolla, California 92092-0208, USA
}

\begin{abstract}
The study of marine bird ecology at sea is complicated by the tendency of many species to follow and otherwise attend vessels. Vessel-attraction likely biases abundance estimates and blurs the correlation between seabird distributions and habitat features over scales of tens of kilometers. Moreover, ship-following behavior inhibits the statistical analysis of seabird distributions because samples too closely spaced in time and space are not independent. These biases have important implications when estimating the size of rare and endangered seabird populations and the prey consumption by abundant species. This paper illustrates how observations of seabird vessel-attendance can be used to mitigate the biases of vessel-attraction and ship-following behavior. I quantified the degree of albatross attraction to survey vessels off southern California, and estimated that standard $300 \mathrm{~m}$ strip transects overestimated their abundance by at least a factor of 3.57. Additionally, I modeled albatross ship-following behavior, and determined that $95 \%$ of recognizable black-footed (Phoebastria nigripes) and Laysan (P. immutabilis) albatrosses ceased to follow the survey vessel after 60 and 38 min respectively. Using these models, I estimated that standard survey methods overestimated black-footed albatross abundance by a factor of 1.17 due to their ship-following behavior. When the vessel-attraction and ship-following biases were combined, standard survey techniques overestimated albatross squid consumption off southern California by a factor of 4 . Determining the degree of vessel-attraction and the temporal scale of ship-following behavior will help design and analyze seabird surveys. These improvements will enhance our ability to monitor the distribution, abundance, and prey consumption of seabird populations.
\end{abstract}

KEY WORDS: Black-footed albatross - Laysan albatross · Autocorrelation - Vessel attendance · Vessel attraction $\cdot$ Seabird surveys $\cdot$ Seabird populations $\cdot$ Food consumption

\section{INTRODUCTION}

The study of pelagic seabirds is complicated by the tendency of many species to follow the vessels used to survey their distributions (Griffiths 1981, La Cock \& Schneider 1982, Tasker et al. 1984, Hudson \& Furness 1989, Garthe \& Huppop 1994). Yet, an accurate understanding of seabird distribution and abundance is important because it provides valuable information

*E-mail: khyrenba@coast.ucsd.edu about fluctuations in marine ecosystems. Bird populations can be used to monitor ecosystem structure because they forage on zooplankton, fish and squid that are often difficult to sample by conventional means (Hunt et al. 1996, Furness \& Camphuysen 1997). Additionally, estimates of seabird prey consumption are vital in understanding energy flow in marine ecosystems. Seabirds can have considerable impacts on local marine resources because they have high energetic requirements and often forage in localized regions close to their colonies (Wiens \& Scott 1975, Hunt et al. 1981, Briggs \& Chu 1987). Overall, seabirds consume a 
substantial ( 3 to $7 \%$ ) proportion of the tertiary production (Furness \& Cooper 1982, Schneider \& Hunt 1982, Briggs \& Chu 1987, Duffy et al. 1987), often forage on species that are commercially harvested (Furness \& Tasker 1996, Furness \& Camphuysen 1997), and frequently exploit fishery discards (Garthe et al. 1996, Camphuysen \& Garthe 1997). Thus, it is important to incorporate estimates of avian prey consumption into multi-species fisheries models, and ecosystem-level management schemes (Croxall 1989, Furness \& Tasker 1996, PICES 2000).

In addition, the accurate determination of at-sea bird abundance patterns provides valuable information about population sizes and foraging areas important for seabird conservation (Spear et al. 1995, Woehler 1996). In particular, a better understanding of albatross and petrel (Procellariiformes) dispersion is urgently needed because recent evidence suggests that many of their populations are declining precipitously (Woehler 1996, Croxall 1998). Yet, it is inherently difficult to survey albatross populations at sea because their behavior is influenced by the presence of fishing and research vessels (Wahl \& Heinemann 1979, Griffiths 1982, La Cock \& Schneider 1982).

Vessel-attendance behavior complicates studies of seabird distribution and abundance in a variety of ways. First, it likely biases abundance estimates, since birds attracted to the vessel are drawn into the survey transect, thus inflating their apparent density. Second, shipfollowing may also bias abundance estimates when observers inadvertently record the same individuals repeatedly (Tasker et al. 1984, Warham 1990). Shipfollowing behavior may also distort our perspective of seabird distributions by blurring the coherence between sightings and mesoscale habitat features (10s to 100s of kilometers). For instance, during surveys in the Southern Ocean, Murphy (1936) reported that northbound ships sighted wandering albatrosses Diomedea exulans farther north than did observers on southbound vessels. Similarly, Thompson (1951) reported shifts in the peak of black-footed albatross Phoebastria nigripes abundance during eastbound and westbound cruises between Hawaii and California, suggesting that ship-following birds ventured farther into subtropical waters while in pursuit of westbound vessels.

Another implication of ship-following behavior is that it inhibits the statistical analysis of seabird sightings, since samples that are too closely spaced in time and space are not independent. The most powerful statistical analyses require independent samples taken randomly from a population of interest (Zar 1984). The lack of sample independence often leads to the false rejection of the null hypothesis (type I error), and to the distortion of the inference space (e.g., pseudoreplication, Hurlbert 1984).
Marine ornithologists have used a variety of methods to deal with vessel-attendance behavior. The simplest approach is to avoid recounting ship-followers recognizable by natural (e.g., plumage coloration and molting) or anthropogenic (e.g., bands and color paint) markings. Yet, this approach assumes that all birds have individual markings, and that observers can recognize every ship-following individual (Tasker et al. 1984).

Alternatively, observers can separate their samples to decrease the probability of recounting ship-following birds. For instance, instead of averaging continuous counts into standard 10 min bins (Tasker et al. 1984), observers can record the maximum number of birds sighted at once (e.g., maximum flock size) during a larger sampling unit, such as a transect, a day, or an entire cruise (Thompson 1951, Sanger 1970). The selection of the smallest sampling unit represents a delicate balance between ensuring sample independence, and surveying seabird distributions at the finest possible resolution. This choice is often based on quantitative measurements of seabird behavior and autocorrelation (La Cock \& Schneider 1982, Schneider 1990), though it is frequently dictated by the observer's prior experience and 'gut feeling' (Wahl \& Heinemann 1979, Ryan \& Moloney 1988).

In this paper, I demonstrate how behavioral observations can be used to mitigate the biases of vesselattraction and ship-following behavior. This study focuses on the black-footed (Phoebastria nigripes) and the Laysan ( $P$. immutabilis) albatross, 2 North Pacific species with broad ranges (from California to Japan and from Hawaii to the Bering Sea) and large populations (60 000 and 500000 breeding pairs respectively) (Gales 1998). I use observations of albatross attendance at survey vessels (1) to estimate a coefficient of vessel-attraction, and (2) to model ship-following behavior. Then, I employ these correction factors to calculate 'corrected' albatross abundances devoid of the biases of vessel-attraction and ship-following. Finally, I illustrate the implications of these improved abundance estimates by contrasting the summertime prey consumption of black-footed albatross populations off southern California, calculated with and without the correction factors I developed.

\section{METHODS}

Seabird observations. I made observations of the ship-attendance behavior of black-footed and Laysan albatrosses, hereafter referred to as BFALs and LYALs respectively, during 16 California Cooperative of Oceanic Fisheries Investigations (CalCOFI) cruises between August 1996 and April 1999. Cruises routinely 
surveyed a grid of hydrographic stations extending between 29 and $35^{\circ} \mathrm{N}$, and from the southern California coast to $124^{\circ} \mathrm{W}$. The data presented here comprise $194 \mathrm{~d}$ at sea and over $19800 \mathrm{~km}$ of survey effort.

Observations started at dawn or upon departure from a station and continued during all daylight hours while the vessel was underway at speeds between 7 and 10 knots (Garthe \& Huppop 1999). I determined whether albatrosses were attracted to the survey vessel by quantifying at what distance from the trackline they first entered an unbounded survey transect, extending in a $90^{\circ}$ arc from the bow to the side of best visibility (Griffiths 1982). I used a hand-held range-finder to estimate the perpendicular distance to every albatross sighted within this survey transect (Heinemann 1981), and scored each sighting into 1 of 4 distance bins (0-300, 300-600, 600-900 and 900-1200 m). I ignored sightings beyond this threshold because I was not certain I could detect every bird at increasing distances.

Additionally, I surveyed albatrosses using standard $300 \mathrm{~m}$ strip transects and 'snap-shot' counts of flying birds, to mimic the methods commonly employed by seabird observers (Tasker et al. 1984). I also recorded every time any albatross entered a $300 \mathrm{~m}$ transect extending from the bow (directly ahead) to $90^{\circ}$ off the side with best visibility (e.g., least glare) using a microcomputer with a resolution of $6 \mathrm{~s}$ (0.1 min). I used these data to calculate the duration of the intervals between successive instances a recognizable individual entered the survey transect (Fig. 1). In determining these intervals, I limited my analyses to birds that were recognizable by their distinct coloration (e.g., extent of white on head, rump and wings for BFALs, and extent of black and white blotches on underwings for LYALs) and molting patterns (e.g., missing primary and secondary feathers).

Analysis of ship-attraction. I quantified the degree to which vessel attraction inflated albatross densities measured with standard $300 \mathrm{~m}$ strip transects using the following 'coefficient of attraction' (CA):

$$
\mathrm{CA}=\left(1 / P_{300}\right)(300 / w)
$$

such that

$$
D_{w}=D_{300} \mathrm{CA}
$$

where $P_{300}$ is the proportion of all sightings that occurred within the $300 \mathrm{~m}$ strip, $w$ is the width of the broadest strip transect used in the survey (e.g., the 'identification horizon', Weins et al. 1978), $D_{300}$ is the density estimated using standard $300 \mathrm{~m}$ strip transects, and $D_{W}$ is the extrapolated density estimated using the broadest strip width ( $w=1200 \mathrm{~m}$ in this case). Thus, the 'coefficient of attraction' allows observers to extrapolate albatross densities out to $1200 \mathrm{~m}$ using counts from standard $300 \mathrm{~m}$ survey transects. A coeffi-
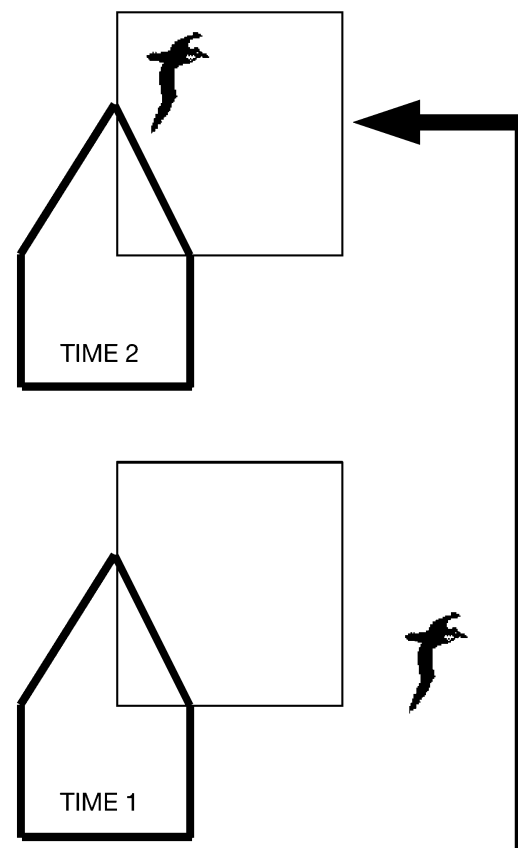

INTERVAL

DURATION

(TIME 2 - TIME 0)

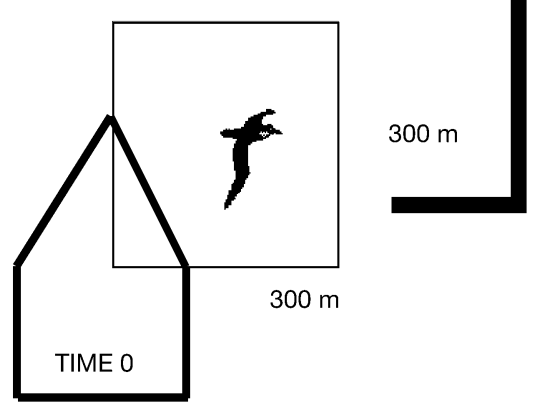

Fig. 1. Time intervals between repeated sightings of recognizable albatrosses were recorded. A sighting was defined as each time a bird entered the $300 \mathrm{~m}$ by $300 \mathrm{~m}$ survey transect

cient of attraction equal to 1 describes a uniform distribution of bird sightings from the trackline to the 'identification horizon'. Conversely, coefficients larger (smaller) than 1 imply that a disproportionate number of birds are sighted outside (within) the $300 \mathrm{~m}$ strip transect. These deviations from the expected uniform distribution suggest that the birds are flying towards (away) from the survey vessel.

Analysis of ship-following. Albatross vessel-attendance consists of a series of brief visits punctuated by forays away from the ship. Thus, albatross sightings occur in clusters, as ship-following birds repeatedly circle the moving vessel every few minutes. I termed the period during which a recognizable albatross followed the survey vessel a ship-following bout. Bouts consist of several repeated visits separated by intervals of varying length, and they end when the bird abandons the vessel permanently or when the survey is 
interrupted by dusk or by arrival at a station. During at-sea surveys, I sighted a total of 793 BFALs and 126 LYALs. I recorded the duration of 233 intervals during 93 ship-following bouts for BFALs, and 43 intervals during 12 bouts for LYALs (Table 1).

Repeated sightings of an albatross during a ship-following bout may not be statistically independent of each other, if the intervals between them are autocorrelated. For instance, autocorrelated intervals between successive visits may remain constant, or may become progressively longer or shorter. While independent albatross visits can be analyzed separately, autocorrelated intervals have to be combined and analyzed together within the context of a ship-following bout. I determined whether there was a significant relationship between the duration of successive intervals within ship-following bouts using simple linear regression. Since interval durations for both BLALs (1-sample Kolmogorov-Smirnov [K-S] test, $k=233$, max. diff. $=$ $0.225, \mathrm{p}<0.001)$, and LYALs (1-sample K-S test, $k=43$, max. diff. $=0.304, \mathrm{p}<0.001)$ were non-normal, I log transformed $\left(x^{\prime}=\log x\right)$ the interval duration data before I performed the linear regressions (Zar 1984).

Additionally, before I could combine all interval durations for subsequent analyses, I had to determine whether individual birds differed in the extent of their ship-following behavior. Combining data from individuals with significantly different behaviors would yield misleading results and would distort the inference space (Hurlbert 1984). I tested for individual differences in the duration of BFAL and LYAL ship-following intervals using non-parametric Kruskal-Wallis tests (Zar 1984).

Next, I determined whether the ship-following behavior varied during different periods of the day or across seasons. Significant temporal differences would require the formulation of distinct ship-following models for specific seasons and periods of the day. I performed 2-way analyses of variance (ANOVAs) of shipfollowing interval durations with season (winter: December-March, spring: April-June, summer: JulyAugust, and fall: September-November) and time of the day (morning: 05:00-12:00 $\mathrm{h}$, and afternoon: 12:00-19:00 h) as fixed factors (Zar 1984). I divided the day into morning and afternoon periods because previ- ous studies have documented diel cycles in albatross vessel-attendance behavior (King 1970, La Cock \& Schneider 1982). After performing the ANOVAs, I tested the residuals for normality using 1-sample K-S tests (Zar 1984). All statistical tests were performed using the Systat 7.0 software package (SPSS Inc., Evanston, IL) and significance was determined at the 0.05 alpha level (Wilkinson 1997).

Exponential model of ship-following behavior. La Cock \& Schneider (1982) successfully described wandering albatross ship-following behavior in the Indian Ocean using the exponential decay process of the form:

$$
P_{\mathrm{f}}(t)=N_{t} / N_{0}=\exp (-k t)
$$

where $P_{\mathrm{f}}(t)$ is the proportion of albatrosses still attending the vessel after time $t, N_{0}$ is the initial number of ship-following birds, $N_{t}$ is the number of albatrosses following the vessel after time $t$, and $k$ is the instantaneous departure rate at which the birds cease to follow the ship. This is the simplest formulation of ship-following behavior because it assumes that the extinction rate $(k)$ is constant regardless of the elapsed time. In other words, the probability that an albatross will revisit the vessel per unit time is held constant.

Weibull model of ship-following behavior. An alternative formulation of albatross ship-following behavior allows the departure rate $(k)$ to change as the elapsed time increases. The Weibull model, developed by Waloddi Weibull (1939) to describe the failure rate of materials, has been used to model a variety of natural phenomena such as the interval between forest fires and species extinctions (e.g., Parker \& Arnold 1997, Polakow \& Dunne 1999).

The Weibull model has the following form:

$$
P_{\mathrm{f}}(t)=N_{t} / N_{0}=\exp \left(-A t^{B}\right)
$$

It is obtained by replacing the constant departure rate $(k)$ in the simpler exponential formulation with the expression $A t^{(B-1)}$, where $A$ and $B$ are constants greater than zero. If $B$ is less than 1 , the departure rate declines with time, while a $B$ greater than 1 yields an increasing departure rate as time increases. The exponential formulation can be considered a special case of the Weibull model, where $B=1$ and $A=k$.

Table 1. Summary statistics for black-footed (BFAL) and Laysan (LYAL) albatross ship-following bouts

\begin{tabular}{|llcrrr|}
\hline \multirow{2}{*}{ Species } & \multicolumn{1}{c|}{ Variable } & Median & Mean & SD & Range \\
\hline \multirow{2}{*}{ BFAL } & Number of visits per bout & 2 & 2.5 & 2.3 & $1-13$ \\
& Total bout duration (min) & 22.9 & 36.8 & 37.5 & $0.4-173.8$ \\
\multirow{2}{*}{ LYAL } & Number of visits per bout & 2.5 & 3.4 & 3.3 & $1-11$ \\
& Total bout duration (min) & 12.8 & 24.4 & 35.3 & $1-127.1$ \\
& & & & 12 \\
\hline
\end{tabular}


Model fitting. I used the maximum likelihood algorithm in the Systat 7.0 nonlinear regression module to fit the 2 models. Because the 2 formulations used a different number of parameters, I contrasted their performance using the metric

$$
C p=\mathrm{SSQ} /(n-2 p)
$$

where $n$ is the sample size, $p$ is the number of parameters in each model, and SSQ is the sum of the squared deviations for each model. In $C p$, above, the numerator quantifies the fit of each model to the data, while the denominator represents the penalty for increasing the number of parameters. Thus, this metric represents a balance between the number of parameters used in a model and that model's fit to the observed data. The formulation with the smallest $C p$ value is the most desirable model, since it provides the best fit to the data normalized by the number of parameters used (Efron \& Tibshirani 1993, Hilborn \& Mangel 1997).

Time to independence. The amount of time necessary to ensure that 2 albatross counts are not correlated has been termed the 'time to independence' (La Cock \& Schneider 1982). I defined this threshold as the amount of time required to ensure that $95 \%$ of ship-following birds would have departed the vessel according to the exponential and Weibull models. This definition is based on the usual alpha level (0.05) used for statistical testing (Zar 1984), and can be modified (e.g., $P_{\mathrm{f}}=50,25$, and $5 \%$ ) to check how sensitive the resulting abundance estimates are to the probability level defining 'time to independence'.

Model performance. Once the ship-following models had been formulated, the next step was to test their predictions of the amount of time albatrosses would follow the survey vessel (e.g., time to independence). I made additional observations of BFAL ship-following behavior during $24 \mathrm{~d}$ at sea and $1580 \mathrm{~km}$ in August and
October of 1999. This time, I recorded birds that entered the survey transect whether they were recognizable individuals or not, to mimic the 'uncorrected' abundance estimates apparent to a naïve observer. Additionally, I estimated the 'minimum' albatross abundance by recording the largest number of birds sighted at once (e.g., maximum flock size) during each transect (Table 2). This index is regularly used to census problematic ship-following birds because it provides a conservative estimate of their abundance, which does not depend on the assumption that observers can recognize all ship-following individuals (Thompson 1951, Sanger 1970).

I also used the best-fit Weibull model to estimate a 'filtered' albatross abundance for each transect. I employed the time to independence predicted by the model to remove likely repeated sightings of ship-following birds recorded by a naïve observer. I filtered the uncorrected data by removing any albatross sightings that occurred up to 60 min (the time to independence predicted by the Weibull model using a $P_{\mathrm{f}}$ value of $5 \%$ ) after a previous sighting of another bird of the same age class. I calculated uncorrected, minimum, and filtered, albatross encounter rates (birds $\mathrm{km}^{-1}$ ) by dividing the total number of birds sighted by the distance surveyed during each transect (Table 2). Finally, I assessed the model's performance by contrasting the uncorrected and filtered encounter rates with the minimum estimate using linear regression.

Implications of improved abundance estimates. In order to illustrate the biological significance of the correction factors developed here, I estimated the size and the consumption of summertime (June to August) BFAL populations off southern California using a variety of methods.

I estimated BFAL average densities (birds $\mathrm{km}^{-2}$ ) using data from seabird surveys on board CalCOFI cruises during the summers of 1996 to 1999. I pro-

Table 2. Definitions of albatross abundance used in this study. CA: coefficient of attraction

\begin{tabular}{|c|c|c|c|c|c|}
\hline Definition & $\begin{array}{l}\text { Strip width } \\
\text { (m) }\end{array}$ & Formulation & $\begin{array}{l}\text { Ship-attraction } \\
\text { correction }\end{array}$ & $\begin{array}{l}\text { Ship-following } \\
\text { correction }\end{array}$ & Source \\
\hline Uncorrected & 300 & $\begin{array}{c}\text { No. of birds/ } \\
\text { distance surveyed }\end{array}$ & None & None & - \\
\hline Standard & 300 & $\begin{array}{c}\text { No. of birds/ } \\
\text { distance surveyed }\end{array}$ & None & $\begin{array}{l}\text { Observer avoids recounting } \\
\text { recognizable birds }\end{array}$ & Tasker et al. (1984) \\
\hline Minimum & 300 & $\begin{array}{l}\text { Maximum flock size/ } \\
\text { distance surveyed }\end{array}$ & None & $\begin{array}{c}\text { Maximum flock size } \\
\text { used as minimum estimate }\end{array}$ & $\begin{array}{l}\text { Thompson (1951), } \\
\text { Sanger (1970) }\end{array}$ \\
\hline Filtered & 300 & $\begin{array}{c}\text { No. of birds/ } \\
\text { distance surveyed }\end{array}$ & None & Time to independence & $\begin{array}{l}\text { La Cock \& Schneider } \\
\text { (1982) }\end{array}$ \\
\hline Extrapolated & 1200 & Standard * CA & $\mathrm{CA}$ & None & Wiens et al. (1978) \\
\hline Corrected & 1200 & Filtered $*$ CA & $\mathrm{CA}$ & Time to independence & - \\
\hline
\end{tabular}


duced 4 BFAL abundance estimates per cruise: (1) the 'standard' density was calculated by dividing the number of albatrosses sighted, after discounting recognizable ship-followers, by the area surveyed using $300 \mathrm{~m}$ strip transects (Tasker et al. 1984); (2) the 'extrapolated' abundance was estimated by multiplying the standard estimate by the CA $(0.28)$; (3) the 'filtered' density was calculated by removing repeated sightings from the standard data using the best-fit Weibull model with a $P_{\mathrm{f}}$ of 0.05 (60 min); and (4) the 'corrected' density was obtained by multiplying the filtered abundance by the CA(0.28). Thus, the standard density was susceptible to the vessel-attraction and ship-following artifacts, the extrapolated abundance was affected by the ship-following bias but not by vessel-attraction, the filtered estimate was biased by vessel-attraction but not by ship-following, and the 'corrected' density was free of both artifacts (Table 2). Since repeated sightings of recognizable individuals had already been discounted from the 'standard' densities, this comparison specifically addresses the bias derived from the observer's inability to recognize individual ship-following albatrosses without distinct markings.

Next, I estimated the size of summertime BFAL populations within the CalCOFI grid by multiplying each average density estimate (birds $\mathrm{km}^{-2}$ ) by the size of the survey area $\left(3 \times 10^{5} \mathrm{~km}\right)$. Once population sizes had been estimated, the next step was to determine the prey consumption of an individual albatross. I used the allometric equation of Birt-Friesen and coworkers (1989) and published data on North Pacific seabird body masses (PICES 2000) to estimate the likely consumption of a BFAL of average body mass $(3.1480 \mathrm{~kg})$. I divided the resulting daily consumption rate $\left(4000.1 \mathrm{~kJ} \mathrm{~d}^{-1}\right)$ by the assimilation efficiency employed by the North Pacific Marine Science Organization (PICES) $(75 \%$, Furness \& Tasker 1996, PICES
2000) to calculate the daily per capita energetic needs of an individual bird. Similar to PICES Working Group 11, I assumed that BFALs remain within the CalCOFI region between June and August (92 d) (PICES 2000). Using this occupancy rate and the population sizes described above, I calculated the summertime consumption for the entire BFAL population off southern California. Finally, I translated these energetic demands into the weight of large cephalopods that the entire population would consume. Like PICES, I assumed that BFALs feed predominantly on large squid (diet is $75.9 \%$ by weight neon flying squid Ommastrephes bartrami, Gould et al. 1997) with an energetic value of $4 \mathrm{~kJ} \mathrm{~g}^{-1}$ (Furness \& Tasker 1996, PICES 2000).

\section{RESULTS}

\section{Vessel attraction}

The incidence of albatrosses between 0 and $1200 \mathrm{~m}$ from the trackline suggests that these birds were attracted to the survey vessel. Both BFALs (1-sample $\mathrm{K}-\mathrm{S}$ test, $k=4$, max. diff. $=0.69, \mathrm{p}=0.019)$ and LYALs (1-sample K-S test, $\mathrm{k}=4$, max. diff. $=0.68, \mathrm{p}=0.022$ ) occurred disproportionately closer to the ship than would have been expected by chance, under a null hypothesis of no attraction or repulsion. The majority ( $90 \%$ of BFALs and $89 \%$ of LYALs) of the albatrosses censused was sighted within the $300 \mathrm{~m}$ survey strip, and $96 \%$ of the individuals of both species occurred within $600 \mathrm{~m}$ of the trackline (Fig. 2). Using $P_{300}$ values of 0.9 and 0.89 for BFALs and LYALs respectively, I estimated a vessel-attraction correction factor (CA) of 0.28 for both species. Thus, standard $300 \mathrm{~m}$ surveys overestimated albatross densities by at least a factor of $1 / 0.28=3.57$.

Table 3. Descriptive statistics of black-footed (BFAL; Phoebastria nigripes) and Laysan (LYAL; P. immutablis) albatross ship-following intervals during different seasons (winter: December-March, spring: April-June, summer: July-August, fall: September-November), and periods of the day (morning: 05:00-12:00 h, afternoon: 12:00-19:00 h). Intervals refer to the amount of time (in min) between successive instances a recognizable albatross entered the survey transect (Fig. 1)

\begin{tabular}{|c|c|c|c|c|c|c|c|c|c|c|c|}
\hline \multirow[t]{2}{*}{ Species } & \multirow[t]{2}{*}{ Season } & \multicolumn{5}{|c|}{ Morning } & \multicolumn{5}{|c|}{ Afternoon } \\
\hline & & Median & Mean & $\mathrm{SD}$ & Range & $\begin{array}{l}\text { Sample } \\
\text { size (n) }\end{array}$ & Median & Mean & $\mathrm{SD}$ & Range & $\begin{array}{l}\text { Sample } \\
\text { size (n) }\end{array}$ \\
\hline \multirow[t]{4}{*}{ BFAL } & Winter & 5.75 & 6.9 & 6.5 & $0.4-24.1$ & 12 & 10.3 & 12.8 & 14.1 & $0.1-53.9$ & 23 \\
\hline & Spring & 6.2 & 12.4 & 16.3 & $0.4-82.2$ & 50 & 9.8 & 19.8 & 25.4 & $0.2-112.5$ & 72 \\
\hline & Summer & 6.3 & 20.2 & 29 & $1.0-09.8$ & 15 & 18.9 & 21.2 & 22.3 & $0.2-92.2$ & 17 \\
\hline & Fall & 5.8 & 10.5 & 11.9 & $0.2-48.4$ & 27 & 5.1 & 17.0 & 22.5 & $1.1-83.6$ & 17 \\
\hline \multirow[t]{2}{*}{ LYAL } & Winter & 2.2 & 4.7 & 5.3 & $0.4-13.2$ & 6 & 2 & 7.6 & 15.6 & $0.1-8.1$ & 28 \\
\hline & Spring & 2.75 & 6.6 & 9.2 & $0.2-23.9$ & 6 & 4.6 & 4.1 & 1.1 & $2.9-4.9$ & 3 \\
\hline
\end{tabular}




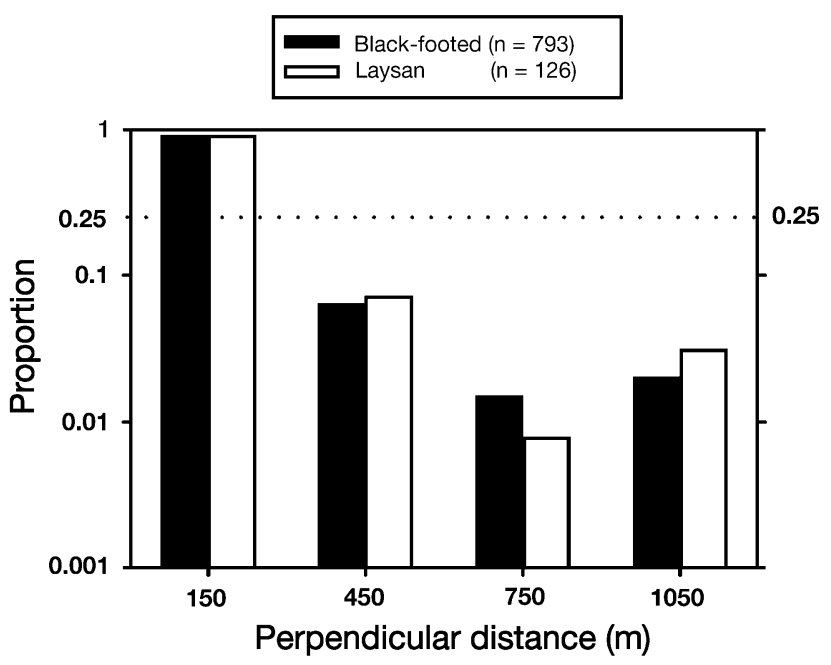

Fig. 2. Observed frequency distribution of perpendicular sighting distances for black-footed (BFAL; Phoebastria nigripes) and Laysan (LYAL; P. immutablis) albatrosses off southern California. Dotted line: expected frequency distribution for neutral birds neither attracted to, nor repelled by the vessel

\section{Description of ship-following behavior}

Albatross ship-following behavior was highly variable (Table 3). Within bouts, intervals between successive visits ranged from 0.1 to $112.5 \mathrm{~min}$ (Fig. 3), while entire ship-following bouts lasted between 0.4 and $173.8 \mathrm{~min}$ (Table 1). Additionally, repeated visits within a bout were not autocorrelated. The duration of intervals between successive sightings of recognizable BFALs (simple regression, $\mathrm{df}=1,141, F=0.847, \mathrm{p}=0.359$ ) and LYALs (simple regression, $\mathrm{df}=1,29, F=0.195, \mathrm{p}=0.662$ ) were not significantly related to each other. In other words, observers could not predict when an individual bird would re-enter the survey transect, given the duration of the previous ship-following interval (Fig. 4).

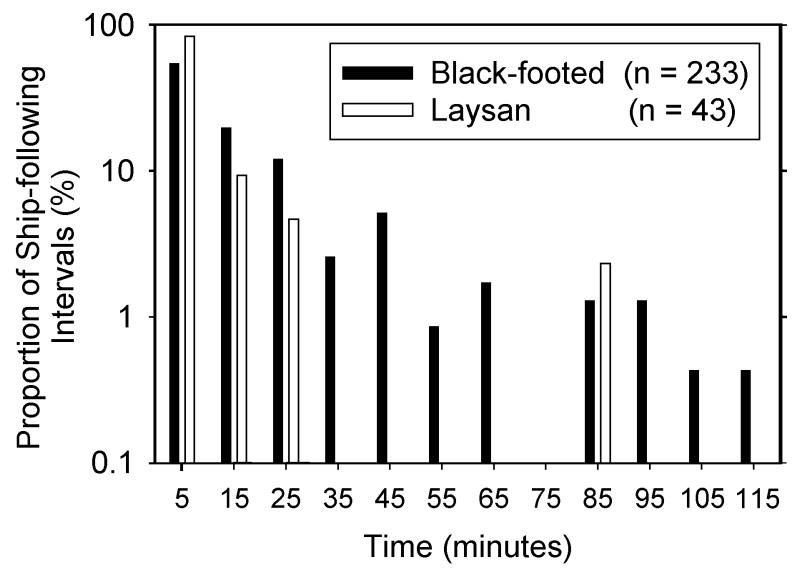

Fig. 3. Duration of ship-following intervals for black-footed (BFAL) and Laysan (LYAL) albatrosses off southern California

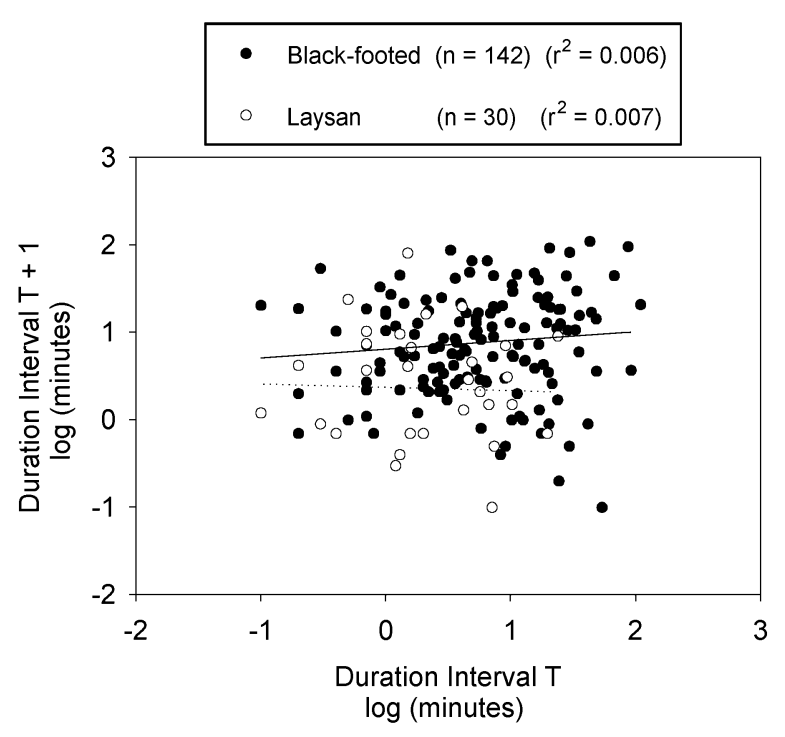

Fig. 4. Relationship between the duration of successive shipfollowing intervals for black-footed (BFAL, solid line) and Laysan (LYAL, dotted line) albatrosses off southern California
Table 4. Results of 2-way ANOVA of $\log$ transformed $\left(x^{\prime}=\log x\right)$ ship-following interval durations for black-footed (BFAL) and Laysan (LYAL) albatrosses during different seasons (winter, spring, summer, fall), and periods of the day (morning, afternoon). NS: not significant

\begin{tabular}{|llcccccc|}
\hline Species & Source & SS & df & MS & F-ratio & p & Significance \\
\hline BFAL & Season & 2.139 & 3 & 0.713 & 1.894 & 0.131 & NS \\
& Period & 0.849 & 1 & 0.849 & 2.257 & 0.134 & NS \\
& Season $\times$ Period & 0.130 & 3 & 0.043 & 0.116 & 0.950 & NS \\
& Error & 84.689 & 225 & 0.376 & & & \\
LYAL & Season & 0.046 & 1 & 0.046 & 0.112 & 0.739 & NS \\
& Period & 0.141 & 1 & 0.141 & 0.341 & 0.562 & NS \\
& Season $\times$ Period & 0.055 & 1 & 0.055 & 0.133 & 0.717 & NS \\
& Error & 16.083 & 39 & 0.412 & & & \\
\hline
\end{tabular}

Ship-following intervals were indistinguishable across individuals. I detected no significant differences in the median interval duration of individual BFALs (Kruskal-Wallis, df $=92, H=$ 105.95, $\mathrm{p}=0.151$ ) and LYALs (KruskalWallis, $\mathrm{df}=11, H=10.49, \mathrm{p}=0.487$ ). Moreover, BFAL and LYAL ship-following behavior did not vary temporally. Two-way ANOVAs revealed no significant differences in the duration of ship-following intervals during different periods of the day and seasons (Table 4). 


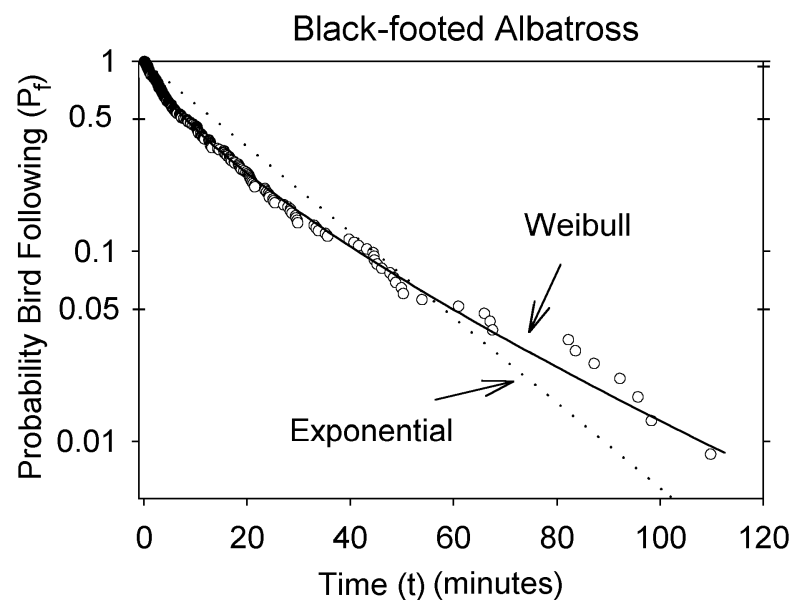

Fig. 5. Comparison of the exponential and Weibull models of black-footed albatross (BFAL) ship-following behavior

\section{Modeling ship-following behavior}

The exponential model of ship-following behavior provided a fairly good fit for both species (Figs. $5 \& 6$ ). However, when compared using the $C_{p}$ metric, the Weibull model described BFAL and LYAL ship-following behavior more accurately (Table 5).

A test of the best-fit Weibull model using additional BFAL observations not used in the model fit, revealed a close agreement between model predictions and conservative estimates of minimum albatross abundance (Fig. 7). Conversely, the uncorrected abundance apparent to a naïve observer overestimated the minimum abundance by a factor of 1.48 (the slope in Fig. 7A). Additionally, model predictions were insensitive to small changes in the definition of $P_{\mathrm{f}}$ (probability of bird continuing to follow the vessel) (Table 6). For instance, $P_{\mathrm{f}}$ values of 0.5 and 0.25 yielded the same abundance estimates (Fig. 7B,C). Finally, model runs using $P_{\mathrm{f}}$ values of 0.05 yielded encounter rates that did not overestimate conservative minimum abundance estimates derived from 'maximum flock size' counts (Fig. 7D).

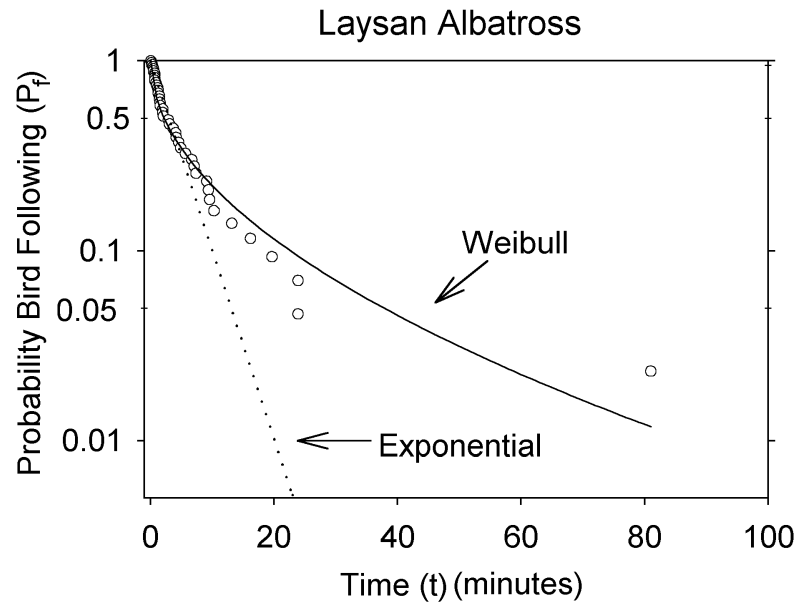

Fig. 6. Comparison of the exponential and Weibull models of Laysan albatross (LYAL) ship-following behavior

\section{Implications of improved abundance estimates}

The corrections developed here yielded BFAL densities that differed by a factor of 4 from the biased abundances calculated using standard censusing techniques (Table 7). Attraction to the vessel had the

Table 6. Comparison of model estimates of albatross departure rates. The 'time to independence' (min) can be defined using a range of probabilities that an individual bird is still following the vessel $\left(P_{\mathrm{f}}\right)$

\begin{tabular}{|lrrrr|}
\hline $\begin{array}{l}\text { Probability bird } \\
\text { following, } \\
P_{\mathrm{f}}=\left(N t / N_{0}\right)\end{array}$ & Exponential & Weibull & Exponential & Weibull \\
\hline 0.95 & 0.63 & 0.22 & 0.70 & 0.01 \\
0.90 & 1.30 & 0.59 & 1.44 & 0.05 \\
0.50 & 8.56 & 7.96 & 9.49 & 2.20 \\
0.25 & 17.11 & 20.72 & 18.99 & 8.48 \\
0.10 & 28.43 & 41.71 & 31.54 & 22.76 \\
0.05 & 36.98 & 59.96 & 41.04 & 37.97 \\
0.01 & 56.85 & 108.51 & 63.08 & 87.66 \\
& & & & \\
\hline
\end{tabular}

Table 5. Results of fitting exponential and Weibull models to black-footed (BFAL) and Laysan (LYAL) albatross ship-following intervals. CI: confidence interval

\begin{tabular}{|lccccccc|}
\hline Species & Model & Parameter & Mean & Lower 95\% CI & Upper 95\% CI & $\mathrm{r}^{2}$ & $C_{p}$ \\
\hline BFAL & Exponential & $k$ & 0.081 & 0.079 & 0.083 & 0.957 & 0.043 \\
& Weibull & $A$ & 0.154 & 0.148 & 0.15 & 0.997 & 0.003 \\
& & $B$ & 0.725 & 0.716 & 0.734 & 0.088 & 0.715 \\
LYAL & Exponential & $k$ & 0.073 & 0.059 & 0.523 & 0.973 & 0.046 \\
& Weibull & $A$ & 0.462 & 0.400 & 0.557 & & \\
& & $B$ & 0.514 & 0.472 & & & \\
\hline
\end{tabular}



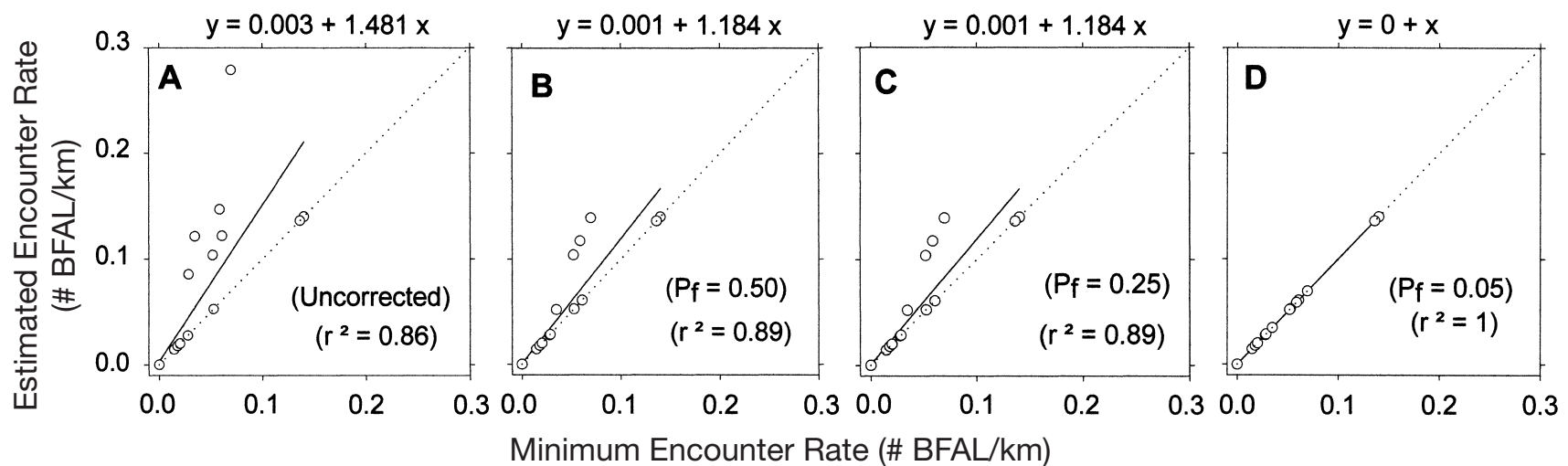

Fig. 7. Test of best-fit Weibull model predictions of black-footed albatross ship-following behavior. (A) Comparison between the 'minimum' (maximum flock size/\# km surveyed) and the 'uncorrected' (unfiltered) encounter rates. (B-D) Comparison of the 'minimum' and the 'filtered' encounter rates after removing likely repeated sightings from the 'uncorrected' data set using the best-fit Weibull model (Table 5). The probability that an individual bird continues to follow the vessel (B: $P_{\mathrm{f}}=0.50 ; \mathrm{C}: P_{\mathrm{f}}=0.25$; D: $\left.P_{\mathrm{f}}=0.05\right)$ is used to define different 'time to independence' thresholds. Sample sizes for each comparison are 70 transects surveyed during August and October 1999

Table 7. Comparison of summertime (June-August) BFAL densities off southern California. See Table 2 for definitions of density estimates

\begin{tabular}{|lccccc|}
\hline $\begin{array}{l}\text { Survey } \\
\text { cruise }\end{array}$ & $\begin{array}{c}\text { Survey } \\
\text { effort } \\
(\mathrm{km})\end{array}$ & $\begin{array}{c}\text { Standard } \\
\text { density } \\
(\text { no. km }\end{array}$ & $\begin{array}{c}\text { Extrapolated } \\
\text { density } \\
\left(\text { no. km }{ }^{-2}\right)\end{array}$ & $\begin{array}{c}\text { Filtered } \\
\text { density } \\
\left(\text { no. km }^{-2}\right)\end{array}$ & $\begin{array}{c}\text { Corrected } \\
\text { density } \\
\left(\text { no. km }^{-2}\right)\end{array}$ \\
\hline Aug 1996 & 1823.95 & 0.0256 & 0.0072 & 0.0201 & 0.0056 \\
July 1997 & 1789.82 & 0.0149 & 0.0042 & 0.0149 & 0.0042 \\
July 1998 & 1780.69 & 0.0187 & 0.0052 & 0.0187 & 0.0052 \\
Aug 1999 & 1470.46 & 0.0385 & 0.0108 & 0.0295 & 0.0083 \\
Mean & & 0.0244 & 0.0068 & 0.0208 & 0.0058 \\
SD & & 0.0104 & 0.0029 & 0.0062 & 0.0017 \\
\hline
\end{tabular}

Table 8. Comparison of summertime (June-August) BFAL population sizes and squid consumption within the CalCOFI grid, off southern California. See Table 2 for definitions of density estimates. Relative trophic impact is expressed as the proportion of the standard prey consumption estimate

\begin{tabular}{|lcrrr|}
\hline Estimate & Standard & Extrapolated & Filtered & Corrected \\
\hline Population size & 7331 & 2053 & 6239 & 1747 \\
$\begin{array}{l}\text { Total energy } \\
\text { requirements } \\
\left(10^{6} \mathrm{~kJ}\right)\end{array}$ & 2730 & 764 & 2324 & 651 \\
$\begin{array}{l}\text { Total squid } \\
\text { consumption (t) }\end{array}$ & 683 & 191 & 581 & 163 \\
$\begin{array}{l}\text { Relative trophic } \\
\text { impact (\%) }\end{array}$ & 100 & 28 & 85 & 24 \\
\hline
\end{tabular}

largest relative effect, with uncorrected densities surpassing average extrapolated densities by a factor of 3.57. Additionally, ship-following behavior inflated the BFAL average standard abundance by a factor of 1.17 . The significance of the correction factors developed here is underscored by the disparity of the prey con- sumption estimates based on biased and unbiased albatross densities (Table 8). The standard and corrected consumption levels differed by $520 \mathrm{t}$, which amounts to approximately $4 \%$ of the average summertime catch of the Korean neon flying squid gillnet fishery for the entire North Pacific between 1983 and 1990 (Gong et al. 1993).

\section{DISCUSSION}

Several studies have documented vessel-attendance by North Pacific albatrosses (Miller 1940, 1942, Yocom 1947, Thompson 1951, Wahl \& Heinemann 1979). Yet, to my knowledge, this is the first attempt to correct biased albatross abundance estimates using information about the extent (e.g., incidence and duration) of vessel-attraction and ship-following. In this paper I illustrated how behavioral observations of ship-following birds can be used to mitigate the biases associated with vessel-attendance. I measured the perpendicular distance to albatross sightings and used this information to estimate the degree of attraction to the survey vessel. I calculated a coefficient of attraction (CA), which I employed to compare albatross densities estimated using standard $(300 \mathrm{~m})$ and extended $(1200 \mathrm{~m})$ transects. This comparison revealed that standard seabird survey protocols overestimated albatross abundance by at least a factor of 3.57. Next, I used repeated sightings of recognizable individuals to model ship-following behavior (time to independence, La Cock \& Schneider 1982). These models revealed 
that standard survey methods overestimated albatross abundance by an additional factor of 1.17. These results suggest that vessel-attraction is a more serious concern than the repeated sightings of ship-following individuals.

This study's findings are in agreement with the notion that, although albatrosses may follow vessels for up to a few days and thousands of kilometers, most ship-following behavior is short-lived (Warham 1990). The maximum BFAL ship-following bout recorded during this study was $174 \mathrm{~min}$, which corresponds to a distance of 29 nautical miles $(52 \mathrm{~km})$ at a cruising speed of 10 knots. Previously, color-marking experiments with BFALs suggested that ship-following was a prevalent, though short-lived phenomenon. Off southern California, $96 \%$ (24 of 25) of the tagged albatrosses were re-sighted, and half of the sightings occurred within less than 20 nautical miles $(36 \mathrm{~km})$ of the marking site (Miller 1940, 1942). Additional observations between San Francisco and Hawaii and off central California, revealed that BFALs followed vessels for up to 4-6 and $12 \mathrm{~h}$ respectively (Yocom 1947, Thompson 1951). The ship-following bouts of north Pacific albatrosses are similar in duration to those previously published for Southern Ocean species. La Cock \& Schneider (1982) reported that wandering albatrosses Diomedea exulans followed their survey vessel for an average of 44 min (SD: 57.2, range: 3-250, n: 14). Similarly, Griffiths (1982) calculated that wandering, shy D. cauta cauta and black-browed D. melanophyrs albatrosses followed research vessels for an average of $80.5,34$ and $17.8 \mathrm{~min}$ respectively.

This research suggests that vessel-attraction inflates standard albatross densities drastically. In fact, it is likely that this study underestimated the extent of vessel attraction because albatrosses aggregate at ships over distances far greater than the $1200 \mathrm{~m}$ 'identification horizon' used to calculate CA (Wahl \& Heinemann 1979, Ryan \& Moloney 1988). The radius over which seabirds aggregate at vessels has been estimated at 4.6 and $3.6 \mathrm{~km}$ respectively for black-browed and shy albatrosses off South Africa (Ryan \& Moloney 1988), and in excess of $6 \mathrm{~km}$ for BFALs off Grey's Harbor, Washington (Wahl \& Heinemann 1979).

The disparity between the magnitude of the vesselattraction (3.57) and ship-following (1.17) biases has important implications for the design of seabird surveys. It suggests that survey methods should focus on the degree to which vessel-attraction inflates apparent bird densities. For instance, measurements of the perpendicular distance to bird sightings (Fig. 2) could be used to calculate species-specific CA and extrapolated densities. Moreover, these CA could be employed in conjunction with maximum flock size counts (e.g., maximum number of birds sighted at once during a transect, Thompson 1951) to mitigate the biases associated with ship-following behavior.

Previous studies suggest that vessel-attendance is a complicated behavior, likely influenced by a myriad of factors (King 1970, Wahl \& Heinemann 1979, Hunt et al. 1981, La Cock \& Schneider 1982, Ryan \& Moloney 1988, Garthe \& Huppop 1999, Nevitt 1999). The tendency of birds to follow and aggregate at ships is likely a function of environmental conditions during surveys (e.g., wind speed and direction, time of the day, visibility), the attractiveness of the vessel (e.g., size, cruising speed, olfactory signature, quantity and type of discarded offal, presence of conspicuous flock-catalyst species such as gulls), the availability of alternative food resources, the prevalence of fishing in the vicinity of the survey area, and inherent qualities of the birds themselves (e.g., time since last meal, previous interactions with fishing vessels).

In particular, there is strong evidence that fishing intensity influences the local abundance of ship-following seabirds, and their tendency to follow vessels (Wahl \& Heinemann 1979, Hunt et al. 1981, Ryan \& Moloney 1988). For instance, BFALs were significantly more abundant off Grey's Harbor during days when fishing boats were present, suggesting that fishing effort influences their distribution over large areas in the order of $10 \mathrm{~s}$ to 100 s of kilometers. Similarly, Hunt and coworkers (1981) reported that in areas of the Bering Sea where fishing fleets were operating, large concentrations of northern fulmars Fulmarus glacialis aggregated in the vicinity of research vessels, even though they provided no food rewards.

Additional research is necessary to determine how the tendency of seabirds to follow and aggregate at ships depends on the nature and the duration of different attracting stimuli, on environmental factors affecting the ability of birds to sense those attractants, and on the background density of birds within the areas surrounding the vessel. Specifically, very little is known about the distance over which seabirds are attracted to survey vessels, and how this distance changes as a function of environmental conditions (Spear et al. 1992). It is likely that the scale of association between vessels and scavengers is influenced by the habits and motility of ship-following species, as well as by the persistence of the attractants eliciting their response. For instance, while BFALs aggregate at large trawlers off Washington state over 10s to 100s of kilometers (Wahl \& Heinemann 1979), there is no association between northern fulmars and fishing boats over similar scales in the North Sea (Camphuysen \& Garthe 1997). Understanding these factors is imperative to convert apparent abundance into the absolute densities required for accurate population size estimates. A starting point would be to contrast the densi- 
ties of ship-following species observed from platforms of varying attractiveness. For instance, Hunt and coworkers (1981) argued that helicopter and vesselbased estimates of northern fulmar densities differed because these birds follow vessels and ignore aircraft.

The techniques discussed here have important implications for the study of large-scale seabird consumption of marine resources, and small-scale marine bird dispersion patterns. Recently, declines in various North Pacific marine bird and pinniped populations, such as those of the Steller sea lion Eumetopias jubatus, Northern fur seal Callorhinus ursinus, blacklegged kittiwakes Rissa tridactyla, and red-legged kittiwakes $R$. brevirostris, have raised concern about possible impacts from competition with fisheries and changes in ecosystem structure (Anonymous 1993, Springer 1998). This uncertainty spurred an ongoing study by PICES to evaluate the prey consumption of marine mammal and seabird populations (PICES 2000).

PICES Working Group 11 divided the basin into 14 sub-areas and estimated seabird abundance within each of these regions using standard population censusing techniques (Tasker et al. 1984, Buckland et al. 1993). For 3 species that are strongly attracted to ships, the apparent total abundance for the entire North Pacific (from all ocean PICES sub-areas combined) exceeded the known world population sizes by a factor of 16.3 (BFAL), 5.6 (northern fulmar), and 1.4 (LYAL). Thus, regional abundances of these species were estimated by dividing the known world populations by the proportion of the apparent density recorded within each sub-area (PICES 2000). Though elegant and resourceful, the proportional allocation of seabird populations based on their apparent at-sea densities may bias estimates of regional seabird prey consumption. This approach assumes that vessel-attraction and shipfollowing bias albatross densities equally across all sub-areas. However, this may not be the case. In particular, fishing effort, which is known to influence seabird distributions and behavior, is not distributed uniformly across the North Pacific (Wahl \& Heinemann 1979, Hunt et al. 1981). An understanding of the way vessel-attendance behavior varies across time and space will help improve regional seabird abundance estimates.

Another important application of the techniques described here is to facilitate small-scale (10s of kilometers) studies of seabird dispersion from fishing and eco-tourism vessels. Opportunistic observations from these platforms, which regularly attract ship-following seabirds with offal, provide valuable information about marine bird seasonal distributions (Wood 1990), vagrancy (Bourne 1967), dispersal of tagged and colormarked birds (Brothers et al. 1997), and coarse-scale habitat preferences (e.g., distance from shore and water depth) (Ryan \& Moloney 1988, Wood 1990, Michaelson et al. 1999). This information is especially important for rare and endangered species, which are often sighted almost exclusively from fishing vessels (e.g., shorttailed albatross Phoebastria albatrus, Sherburne 1993). Yet, these data are non-quantitative because observers cannot circumvent the potential biases of vessel-attendance.

Observations of vessel-attraction and ship-following behavior could be used to improve the design and analysis of seabird surveys (Wahl \& Heinemann 1979, La Cock \& Schneider 1982). La Cock \& Schneider (1982), for instance, used the extent of ship-following behavior to determine the temporal separation (e.g., amount of time) required to ensure the independence of albatross point counts. They determined that in the Indian Ocean wandering albatrosses followed vessels for significantly longer periods during the afternoon (mean $=78.6 \mathrm{~min}, \mathrm{SD}=65.4$, median $=91, \mathrm{n}=7$ ) than during the morning (mean $=9.4 \mathrm{~min}, \mathrm{SD}=4.8$, median $=10, n=7$ ). Accordingly, the size of independent sampling units would have to differ as a function of time of the day: afternoon counts would have to be spaced out farther than samples taken in the morning. This study revealed that BFALs and LYALs followed survey vessels for an average of 36.8 and $24.4 \mathrm{~min}$ respectively (Table 1), and exhibited no diel or seasonal differences in ship-following behavior (Table 4). Thus, off southern California, albatross distributions could be analyzed at the same spatial resolution regardless of time of the day and season, though BFALs would have to be surveyed at a coarser resolution than LYALs.

The techniques described here are important to derive the 'absolute' densities required for accurate estimates of population sizes. Additionally, estimates of seabird abundance corrected for the biases of vesselattendance may provide useful information about changes in marine bird community composition and structure. Changing seabird assemblages are indicative of shifts in water mass distributions, and largescale changes in oceanographic conditions (Hunt et al. 1992, Veit et al. 1996). Specifically, the relative abundance of various albatross species has been used to analyze their response to seasonal changes in ocean temperature (Wood 1990). However, species-specific disparities in the degree of vessel-attraction likely bias our perception of seabird community structure, as the species that follow and aggregate at vessels more avidly are overestimated. For instance, the ratio of BFAL to LYAL abundance off southern California during the cruise when both species were sighted (August 1996) was 7 when standard densities were compared and 5.5 when the biases of ship-attraction and ship-following were removed. 
Absolute densities free of the biases of vessel-attendance are necessary to estimate seabird population sizes and community structure. However, not all studies of seabird dispersion at sea require the correction factors described here. For instance, ornithologists using indices of relative abundance (e.g., birds $\mathrm{km}^{-2}$ ) to describe changes in seabird distribution and abundance do not need to use ship-following corrections, given that their methodology (e.g., areas surveyed, platfoms used, and censusing methods) remains unchanged throughout their study (Veit et al. 1996).

Despite the applicability of the CA and the time to independence corrections, these techniques are subject to changes in seabird behavior across time and space. Thus, these indices should not be applied to historical survey data retrospectively, given that many uncontrolled factors may have influenced the attractiveness of the vessel (e.g., fishing vessels in the area, presence of other flock-catalyst species). On the other hand, these correction factors could be applied to future surveys. Ideally, observers would estimate vessel-attendance correction factors on a survey-specific basis, though in reality, area and time-specific estimates may prove more feasible.

Determining the degree of vessel-attraction and the temporal scale of ship-following behavior will enhance our ability to monitor the distribution, abundance, and prey consumption of seabird populations. The significance of this research is underscored by the large size and the high resource consumption of marine bird populations. The world albatross population alone consists of 24 species and over 2 million breeding birds (Gales 1998).

Acknowledgements. This research was completed as part of the requirements for a $\mathrm{PhD}$ at the Scripps Institution of Oceanography. I gratefully thank the captains and crews of RV 'David Starr Jordan', RV 'New Horizon', RV 'Robert Gordon Sproul' and RV 'Roger Revelle'. Dick Veit furnished the microcomputer and the software used to record seabird observations. Jack Bradbury, Jules Jaffe, and Mandy Toperoff helped with statistics. Paul Dayton, Peter Franks, George Hunt, Jules Jaffe, Libby Logerwell, David Schneider, and 3 anonymous reviewers provided helpful comments on an earlier draft of this manuscript.

\section{LITERATURE CITED}

Anonymous (1993) Is it food? Sea Grant, University of Alaska, Fairbanks

Birt-Friesen VL, Montevecchi WA, Cairns DK, Macko SA (1989) Activity-specific metabolic rates of free-living northern gannets and other seabirds. Ecology 70:357-367

Bourne WRP (1967) Long-distance vagrancy in the petrels. Ibis 109:141-167

Briggs KT, Chu EW (1987) Trophic relationships and food requirements of California seabirds: updating models of trophic impact. In: Croxall JP (ed) Seabirds: feeding eco- logy and role in marine ecosystems. Cambridge University Press, Cambridge, p 279-301

Brothers NP, Reid TA, Gales RP (1997) At-sea distribution of shy albatrosses Diomedea cauta cauta derived from records of band recoveries and color-marked individuals. Emu 97:231-239

Buckland ST, Anderson DR, Burnham KP, Laake JL (1993) Distance sampling: estimating abundance of biological populations. Chapman and Hall, London

Camphuysen CJ, Garthe S (1997) An evaluation of the distribution and scavenging habits of northern fulmars (Fulmarus glacialis) in the North Sea. ICES J Mar Sci 54: $654-683$

Croxall JP (1989) Use of indices of predator status and performance in CCAMLR fishery management. Selected Scientific Papers, 1989. Comm Conserv Antarct Liv Res SC-CAMLR-SSP/6:353-365

Croxall JP (1998) Research and conservation: a future for albatrosses? In: Robertson G, Gales R (eds) Albatross ecology and conservation. Surrey Beatty and Sons Ltd, Chipping Norton, p 269-290

Duffy DC, Sigfried WR, Jackson S (1987) Seabirds as consumers in the southern Benguela region. S Afr J Mar Sci 5:771-790

Efron B, Tibshirani R (1993) An introduction to the Bootstrap. Chapman and Hall, New York

Furness RW, Camphuysen CJ (1997) Seabirds as monitors of the marine environment. ICES J Mar Sci 54:726-737

Furness RW, Cooper J (1982) Interactions between breeding seabirds and pelagic fish populations in the southern Benguela region. Mar Ecol Prog Ser 8:243-250

Furness RW, Tasker ML (1996) Estimation of food consumption by seabirds in the North Sea. ICES Coop Res Rep 216: $6-42$

Gales R (1998) Albatross populations: status and threats. In: Robertson G, Gales R (eds) Albatross ecology and conservation. Surrey Beatty and Sons Ltd, Chipping Norton, p 20-45

Garthe S, Huppop O (1994) Distributions of ship-following seabirds and their utilization of discards in the North Sea. Mar Ecol Prog Ser 106:1-9

Garthe S, Huppop O (1999) Effect of ship speed on seabird counts in areas supporting commercial fisheries. J Field Ornithol 70:28-32

Garthe S, Camphuysen CJ, Furness RW (1996) Amounts of discards in commercial fisheries and their significance as food for seabirds in the North Sea in summer. Mar Ecol Prog Ser 136:1-11

Gong Y, Kim YS, An DH (1993) Abundance of neon flying squid in relation to oceanographic conditions in the north Pacific. Bull Int N Pac Fish Comm 53(II):191-204

Gould P, Ostrom P, Walker W (1997) Trophic relationships of albatrosses associated with squid and large-mesh drift-net fisheries in the North Pacific Ocean. Can J Zool 75: $549-562$

Griffiths AM (1981) Biases in censuses of pelagic seabirds at sea in the Southern Ocean. In: Cooper J (ed) Proceedings of the symposium on birds of the sea and shore, 1979. African Seabird Group, Cape Town, p 189-196

Griffiths AM (1982) Reactions of some seabirds to a ship in the Southern Ocean. Ostrich 53:228-235

Heinemann D (1981) A rangefinder for pelagic bird censusing. J Wildl Manage 45:489-493

Hilborn R, Mangel M (1997) The ecological detective: confronting models with data. Princeton University Press, Princeton

Hudson AV, Furness RW (1989) The behaviour of seabirds foraging at fishing boats around Shetland. Ibis 131:225-237 
Hunt GL Jr, Gould PJ, Forsell DJ, Peterson H (1981) Pelagic distribution of marine birds in the eastern Bering Sea. In: Hood DW, Calder JA (eds) The eastern Bering Sea shelf: oceanography and resources, Vol 2. University of Washington Press, Seattle, p 689-718

Hunt GL Jr, Priddle J, Whitehouse MJ, Veit RR, Heywood RB (1992) Changes in seabird species abundance near South Georgia during a period of rapid change in sea surface temperature. Antarct Sci 4:15-22

Hunt GL Jr, Decker MB, Kitaysky A (1996) Fluctuations in the Bering Sea ecosystem as reflected in the reproductive ecology and diets of kittiwakes on the Pribilof Islands, 1975 to 1991. In: Greenstreet SPR, Tasker ML (eds) Aquatic predators and their prey. Fishing News Book, Oxford, p 142-153

Hurlbert SH (1984) Pseudoreplication and the design of ecological field experiments. Ecology 54:187-211

King WB (1970) The trade wind zone oceanographic pilot study, part 7: observations of seabirds March 1964 to June 1965. US Fish and Wildl Serv Spec Sci Rep, Fish No. 586

La Cock G, Schneider DC (1982) Duration of ship following by wandering albatrosses, Diomedea exulans. Cormorant 10: 105-108

Michaelson J, Wilbor S, Fadely J, Sherburne J, Tande J, Norman FR, Duffy DC (1999) Recent distributional records of short-tailed albatross as a tool for long-line fisheries management. Pacific Seabirds 26(1):29

Miller L (1940) Observations on the black-footed albatross. Condor 42:229-239

Miller L (1942) Some tagging experiments with black-footed albatrosses. Condor 44:3-9

Murphy RC (1936) Oceanic birds of South America. American Museum of Natural History, New York

Nevitt G (1999) Olfactory foraging in Antarctic seabirds: a species-specific attraction to krill odors. Mar Ecol Prog Ser 177:235-241

Parker WC, Arnold AJ (1997) Species survivorship in the Cenozoic planktonic foraminifera: a test of exponential and Weibull models. Palaios 12:3-11

PICES (2000) Predation by marine birds and mammals in the subarctic North Pacific Ocean. In: Hunt GL Jr, Kato H, McKinnell SM (eds) North Pacific Marine Science Organisation Scientific Report 14:1-165

Polakow DA, Dunne TT (1999) Modelling fire-return interval: stochasticity and censoring in the two-parameter Weibull model. Ecol Model 121:79-102

Ryan PG, Moloney CL (1988) Effect of trawling on bird and seal distributions in the southern Benguela region. Mar Ecol Prog Ser 45:1-11

Sanger GA (1970) The seasonal distribution of some seabirds off Washington and Oregon, with notes on their ecology and behavior. Condor 72:339-357

Schneider DC (1990) Spatial autocorrelation in marine birds. Polar Res 8:89-97

Schneider DC, Hunt GL Jr (1982) Carbon flux to seabirds in

Editorial responsibility: David Schneider (Contributing

Editor), St. John's, Newfoundland, Canada waters with different mixing regimes in the southeastern Bering Sea. Mar Biol 67:337-344

Sherburne J (1993) Status report on the short-tailed albatross Diomedea albatrus. Report to US Fish and Wildlife Service, Anchorage, AK. Alaska Natural Heritage Program, University of Alaska, Anchorage

Spear LB, Nur N, Ainley DG (1992) Estimating absolute densities of flying seabirds using analyses of relative movement. Auk 109:385-389

Spear LB, Ainley DG, Nur N, Howell SNG (1995) Population size and factors affecting at-sea distributions of four endangered procellariids in the tropical Pacific. Condor 97:613-638

Springer AM (1998) Is it all climate change? Why marine bird and mammal populations fluctuate in the North Pacific. In: Holloway G, Muller P, Henderson D (eds) Biotic impacts of extratropical climate variability in the Pacific. 'Aha Huliko'a Proceedings, University of Hawaii, Honolulu, p 109-119

Tasker ML, Hope-Jones P, Dixon T, Blake BF (1984) Counting seabirds at sea from ships: a review of methods employed and suggestion for a standardized approach. Auk 101: $567-577$

Thompson DQ (1951) Notes on the distribution of north Pacific albatrosses. Auk 68:227-235

Veit RR, Pyle P, McGowan JA (1996) Ocean warming and long-term change in pelagic bird abundance within the California current system. Mar Ecol Prog Ser 139:1-18

Wahl TR, Heinemann D (1979) Seabirds and fishing vessels: co-occurrence and attraction. Condor 81:390-396

Warham J (1990) The petrels, their ecology and breeding systems. Academic Press Inc, New York

Weibull WA (1939) A statistical theory of the strength of materials. Ingemiors Vetenskaps Akademien Handlingar 151: $1-45$

Wiens JA, Scott JM (1975) Model estimation of energy flow in Oregon coastal seabird populations. Condor 77:439-452

Wiens JA, Heinemann D, Hoffman D (1978) Community structure distribution and interrelationships of marine birds in the Gulf of Alaska. Environ Assess Alaskan Cont Shelf 3:1-178

Wilkinson L (1997) SYSTAT: the system for statistics. Systat Inc, Evanston

Woehler EJ (1996) Concurrent declines in five species of Southern Ocean seabirds in Prydz Bay. Polar Biol 5: 379-382

Wood KA (1990) Seasonal abundance and marine habitats of Procellaria, fulmarine and gadfly petrels off central New South Wales. Notornis 37:81-105

Yocom C (1947) Notes on the behavior and abundance of the black-footed albatrosses in the Pacific waters off the continental North American shores. Auk 64:507-522

Zar JH (1984) Biostatistical analysis. Prentice-Hall Inc, Englewood Cliffs, NJ

Submitted: December 20, 1999; Accepted: September 7, 2000 Proofs received from author(s): January 31, 2001 